\section{SCIENCE:}

\section{A WEEKLY NEWSPAPER OF ALL THE ARTS AND SCIENCES.}

PUBLISHED BY

\section{N. D. C. H O D GES,}

874 Broadway, NeW York.

Groth, Leipzig; November, 1890, pp. 386-389; "Igneous Rocks of Arkansas," Vol. II. of the Publications of the Survey, 1890; "Ueber den Monte Amiata in Toscana und Seine Gesteine" [Mit. Taf., XII.-XVI.]. Neues Jahrbuch für Mineralogie, Geologie und Paleontologie, BB. V. 381, 1886, his most important work; and a volume of some four hundred pages on the mineralogy and petrology of Arkansas, now in press.

\title{
THE COMMON EDIBLE CRAB FOUND FOSSIL IN THE HUDSON RIVER TUNNEL.
}

Subscriptrions.-United States and Canada............\$3.50 a year. Great Britain and Europe............ 4.50 a year.

Communications will be welcomed from any quarter. Abstracts of scientific papers are solicited, and one hundred copies of the issue containing such will be mailed the author on request in advance. Rejected manuscripts will be returned to the authors only when the requisite amount of postage accompanies the manuscript. Whatever is intended for insertion must be authenticated by the name and address of the writer; not necessarily for publication, but as a guaranty of good faith. We do not hold ourselves responsible for any view or opinions expressed in the communications of our correspondents. Attention is called to the "Wants" column. All are invited to use it in soliciting information or seeking new positions. The name and address of applicants should be given in full, so that answers will go direct to them. The "Exchange" column is likewise open.

\section{JOHN FRANCTS WILLIAMS.}

John Francis Williams, Ph.D., assistant professor of geology and mineralogy in Cornell University, died at Tthaca Monday evening, Nov. 9, 1891. Although Dr. Williams was only twenty-nine years of age, he had achieved eminent distinction. He took his baccalaureate degree at the Troy Polytechnic Institute, and afterward studied at Göttingen for three years with such success that when his professor, Dr. Klein, went to Berlin, Dr. Williams accompanied him as assistant. Returning to America, he was appointed curator of the mineralogical and industrial collection of the Pratt Institute of Brooklyn, L.I., which, conjointly with Professor Nason of the Rensselaer Polytechnic Institute of Troy, was formed in Europe. He then became docent in Clark University, and afterwards was employed in a very important part of the State survey of Arkansas. In the course of the survey, extending over two years, he collected minerals for a very complete report on the mineralogy and petrography of the State, a volume of some four hundred pages being now in press. Some of his work has been complimented by Dr. Rosenbusch, the greatest living authority, as among the best he had ever seen done by an American.

Dr. Williams had just entered on his work of instruction in Cornell, when it became apparent that he had brought from the malarious regions of Arkansas the seeds of a fatal disease. His instruction was highly praised by his students, and he was universally esteemed by his colleagues.

Dr. Williams was one of the best of the new school of mineralogists, being thoroughly rounded in his knowledge of the science, being an excellent chemist, crystallographer, petrologist, and geologist.

Dr. Williams was born at the old family homestead, in Salem, N.Y. He was the son of John N. Williams, and belonged to one of the oldest families in New York.

Among his published papers were "Eudialyte and Eucolite, from Magnet Cove, Arkansas," in American Journal of Science, December, 1890; "Manganopectolite from Magnet Cove," Zeitschrift f. Krsstallographie und Mineralogie, P.
DURING work on the Hudson River tunnel, as carried on from the New Jersey side, and when at a distance of about 3,100 feet from the New Jersey opening, one of the workmen noticed a hard nodule among the silt as it was being taken out at the heading, and secured it as an object of curiosity. On being washed thé nodule, which is about six and a half inches long by two and a half wide and an inch thick, was seen to contain quantities of a small sea shell (Mactra lateralis say) and remains of a crab.

Subsequently this nodule, which is of a hard limestone nature on the inside, although soft and muddy externally, came into the possession of William Dutcher, Esq., of this city, who presented it to the American Museum of Natural History, where it will be preserved in section 12 of case $Q$ of the Geological Hall.

On removing some of the stone from the left side of the back, the lateral spine characteristic of our common blue or edible crab (Cullinectes hastatus, Fabricus; =Lupa dicantha, Latreille, of the New York State Natural History, Zoology, plate IIT., fig. 3 is shown, which proves it to be an ancient example, about two-thirds grown, of this much esteemed and highly prized frequenter of our city markets, restaurants, and hotels, as well as of many private tables, although at present by no means in the soft shell condition, for the nodule is su hard internally as to yield only to the action of a hammer and chisel; although externally looking like a nodule of hardened mud. The nodule exposes a little more than half of the upper surface of the back, and parts of each of the large claws; and in removing the stone from the surface, impressions of several leaves were exposed, and a fragment of sea grass.

The finding of this species in a fossilized condition, in the position from which it was taken, is a matter of considerable interest, as it is the only instance known of its existence in a fossil condition. It proves this animal to bave inhabited the shoals and bays of this region for a period dating back to probably long before the advent of man, for its depth below the bottom of the river at that point, which is about thirty-five to forty feet to the centre of the tunnel, together with its perfectly fossilized condition, would indicate the lapse of considerable time since its entombment.

R. P. W.

\section{ASTRONOMICAL NOTES.}

ON May 22, 1886, Mr. W. R. Brooks, then living at Phelps, N.Y., discovered a telescopic comet which has been the subject of an extensive discussion by $\mathrm{Di}^{\mathrm{i}}$. S. Oppenheim of Ottakring. He finds that the comet is a short-period one, of from 5.7 to 6.1 yaars. In No. 3,064 of the Astronomische Nachrichten Dr. Oppenheim publishes a sweeping ephemeris covering the period from Jan. 1 to Sept. 17, 1892.

Previous to his death, Professor Theo. Oppalzer had under bis charge the orbit of the short-period comet discovered by 